\title{
沿道条件を考慮した除雪・消雪道路の選定に関する研究
}

\section{A Study on Snow Countermeasures Considering a Roadside Condition}

\author{
寺 内 義 典*1 - 嶋 由 喜 昭*2 \\ Yoshinori Terauchi Yoshiaki Shimada \\ 本多 義 明*3 \\ Yoshiaki Honda
}

\section{SYNOPSIS}

In snowfall regions, the installation of snow-melting equipment is desirable for residents, but it needs a high price and much groundwater. Now, local government has need of the method for snow-removal.

This paper aims to propose the practical method to select snow-removal and snow-melting roads considering a road land-use condition. Firstly, in this method, roads are classified to any ranks using its function. Secondly, the number of lanes and sidewalks to ensure the road traffic is decided for each rank. Finally, selection of snow-removal or snow-melting is carried out a considering roadside condition.

This method is applied to the actual road network in Sabae-city. The result is used to practical selection of snow-removal and snow-melting.

Keywords : snow-melting, snow-removal, roadside condition

\section{1.はじめに}

降積雪地域における道路への積雪は，自動車・歩 行者交通の障害として問題視されてきた。特に近年 では，モータリゼーションの進展といったライフス タイルの変化，積雪時においても通常時の生活を確 保したいという欲求の増大に伴い，道路の除排雪・ 消雪への要求はより高まってきている。本研究で対 象とする福井県鲭江市では，車線幅員 $6 \mathrm{~m}$ 以上の道 路ではすへて機械除雪が行われているが，2４mの 狭幅員道路への消雪装置設置を市民が要求している。

しかし，消雪装置の設置・運用コストは機械除雪 よりむ高価であり，また地下水の汲み上げにより地 盤沈下が発生するなどの問題むある。現在，新潟な
どの特別豪雪地帯の指定地域においては, 消雪装置 の運用面でのシステムが確立してきている ${ }^{1)}$ が， 毎年定常的な降積雪がみられない地域では，これら の住民の要求にこたえる体制が出来ていない。また， 除雪の可能な道路に対しては，できる限り除雪を行 い，消雪装置を設置することは避ける必要があるに むかかわらず，実際の業務においては，住民の要求 により消雪装置を設置せざるを得ない場合がある。 このようなことから，各自治体は道路を除雪するか， 消雪するかを選択する合理的な手法を必要としてい る。

従来, 道路の除排雪・消雪対策に関する研究がい くつか行われてきた。その多くは，個々の除排雪・

* 1 福井大学大学院工学研究科システム設計工学専攻 修(工)

*2 太同工業大学建設工学科 講師・博(I)

*3 福井大学工学部環境設計工学科 教授・工博

[本稿受理 : 1998年 5 月 25 日, 修正原稿受理 : 1998年 8 月21日, 討論期限 : 1999年 9 月30日] 
消雪方法に関する技術的なむの秋えは2)や除排雪・消 雪の管理運営システムに関するもの的えるである。

しかし，機械除雪のみを対象とした木俣”によ る官民の役割分担を考虑した除雪道路の優先順位の 決定に関する研究がある。また，宮腰ら ${ }^{5)}$ は現在 行われている市街地除排雪・消雪に対する住民の意 識構造の把握と評価の定量化を行っている。その結 果，除雪上りも消雪装置の設置が住民の要望として 強いことが示されている。

本研究では, 都市内の日常交通の確保に必要な雪 害対策をより合理的に策定する手法として，沿道条 件を考慮した除雪・消雪道路の選定手順を作成する。 また，ケーススタティとして，本選定手順の福井県 鯖江市への適用を図る。ここで除雪とは，排雪を伴 わない機械除雪を指し，消雪とはここでの除雪以外 の方法による雪対策全般を指すむので，散水消雪に 限らない。

なお本研究では，近年の危機管理意識の高まりを 考慮し，災害時における緊急路の確保に重点をおく ととむに，行政上の業務に容易に適用できることに

\section{表ー 1 自動車交通における重要度と街路機能}

\begin{tabular}{|c|c|}
\hline 重要度 & 街路機能 \\
\hline $\begin{array}{l}\text { ランク I } \\
\text { 常時交通の確 } \\
\text { 保が必要な道 } \\
\text { 路 }\end{array}$ & 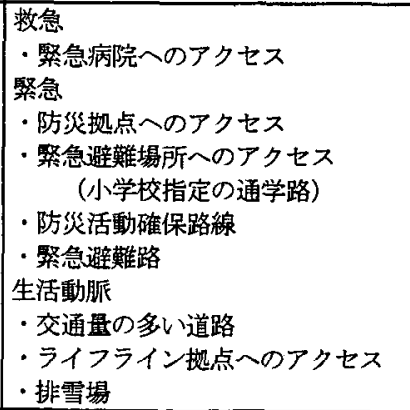 \\
\hline $\begin{array}{l}\text { ランク II } \\
\text { 降稙雪レベル } \\
\text { を超える場合 } \\
\text { でも早朝まで } \\
\text { の交通確保が } \\
\text { 必要な道路 } \\
\end{array}$ & $\begin{array}{l}\text { 通学路線 } \\
\text {-中学校指定の通学路 } \\
\text { ·高等学校主要通学路 } \\
\text { 公共交通 } \\
\text { ・バス路線 } \\
\text { ·鉄道駅へのアクセス }\end{array}$ \\
\hline $\begin{array}{l}\text { ランク III } \\
\text { 早朝までに交 } \\
\text { 通確保が必要 } \\
\text { な道路 }\end{array}$ & $\begin{array}{l}\text { 公共公益施設 } \\
\text { ・その他公共公益施設へのアクセス } \\
\text { ・ 火葬場, 駐車場へのアクセス } \\
\text { ・沿道環境が商業業務を } \\
\text { 中心とししている道路 } \\
\text { ・大規模商業施設へのアクセス } \\
\text { 公共サービス } \\
\text { ・ごみ収集路線 }\end{array}$ \\
\hline
\end{tabular}

む配虑している。

\section{2. 除雪・消雪道路の選定法}

\section{1 街路機能と重要度}

除雪・消雪道路の選定を行うために，まず，交通 確保の必要性により各々の道路の重要度を設定し， その機能を明らかにする。

これらの対象となる道路としては，市街地内の交 通に必要なネットワークを構成するむのとしての 1 ・ 2 級市道, 一般県道以上の道路に加え，公共公益施 設，防災拋点などへのアクセス道路とする。なお， 前提となる降皘雪状態は皘雪梁70～80 cm と仮定する。 この状態を超えた積雪が発生した場合，除雪道路に おいても機械除雪が困難亡なり排雪作業へと移行す るので，その場合には別途考察が必要である。

街路機能と重要度の関係を各種資料所え(86)を参考 にして，自動車交通については表－1，歩行者交通 については表－2のように設定する。設定に際して， 2 次災害の発生を考慮し，特に防災拋点へのアクセ ス，緊急避難経路の確保に重点をおいたむのとして いる。

\section{2 確保すべき車線数と歩道}

自動車交通，歩行者交通それぞれの重要度ランク に必要とされる車線数と歩道の設定方法は，図一 1 に示すとおりである。

第一に，確保すべき車線数を設定する。通常，多

\section{表一 2 歩行者交通における重要度と街路機能}

\begin{tabular}{|c|c|}
\hline 重要度 & 街路機能 \\
\hline $\begin{array}{l}\text { ランク I } \\
\text { 常時安全な通 } \\
\text { 行を確保する } \\
\text { 必要がある道 } \\
\text { 路 }\end{array}$ & 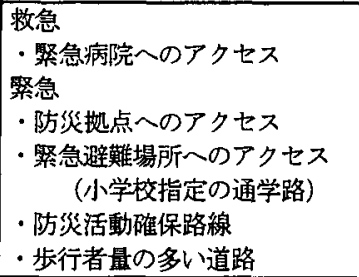 \\
\hline $\begin{array}{l}\text { ランク II } \\
\text { 降㮴雪レベル } \\
\text { を超える場合 } \\
\text { でも早朝まで } \\
\text { の交通確保が } \\
\text { 必要な道路 }\end{array}$ & 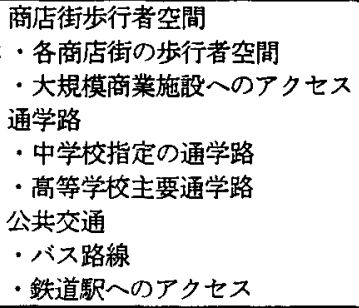 \\
\hline
\end{tabular}






図ー 1 確保すべき車線数と歩道

車線道路については無条件に 2 車線確保とした。つ まり多車線道路は幹線道路として機能することが期 待されており，また，広幅員であることから除雪に よる 2 車線確保が比較的容易であると判断されるた めである。また，ランクIの道路もその重要性から 2 車線確保とした。ランクாの道路では，バス路線, 鉄道駅へのアクセス道路は両方向の交通が円滑に行 われる必要があることから 2 車線確保とした。それ 以外のランク II 道路とランク III の道路では一車線 確保としている。第二に歩行者交通に関しては, 確 保すへき車線に関わらず，緊急性の高いランク I で は両側歩道を確保，ランク IIでは片側歩道を確保と した。
なお、ここで用いる道路の詳細部分の名称を図一 2 に示す。

\section{3 除雪・消雪道路の選定手順}

対象道路に必要とされる道路断面を確保するため の除雪・消雪道路の選定を行うにあたり，沿道条件， 道路や車道部の幅員, 步道の有無などの諸条件を考 虑する必要がある。ここで，その選定手順を作成す るにあたって，その前提となる条件を道路構造令等 を参考に以下のように定める。

・山地・田園地域においては道路の外側に堆雪て きる。

- 車道の最低車線幅員は2.75mとする。

- 歩行幅員, 歩道幅員は原則として $1.0 \mathrm{~m}$ を確保 するべざあるが，最低限度として0.75 m を確 保する。

- 車道用堆雪帯は車道幅員に関係なく一律とし, 二車線確保時は $2.5 \mathrm{~m}$, 一車線確保時は $1.5 \mathrm{~m}$ と する。

・歩行用堆雪帯は一律 $0.5 \mathrm{~m}$ とする。

- 交差点における横断歩道等の確保は, 除雪・消 雪により適宜確保できるむのと考え，特に取り 扱わない。

・䀣存の消雪装置設置路線やアーケードの設㯰さ れた道路については対象外とする。

選定手順は以上の各条件を組み合わせて作成され る。具体的には，行政担当者が容易に選定できるよ うに，各対象道路についての基準をパーソナルコン ピュータ上で選択または問答形式で行えるように配 虑している。最終結果として, 各条件に従った各道 路の適切な処理（a. 道路消雪・步道消雪, b. 道路除 雪・歩道消雪， c. 道路消雪 - 歩道除雪, $\mathrm{d}$. 道路除雪 歩道除雪）が得られるものである。なお，その手順



図ー2 道路の詳細部分の名称 


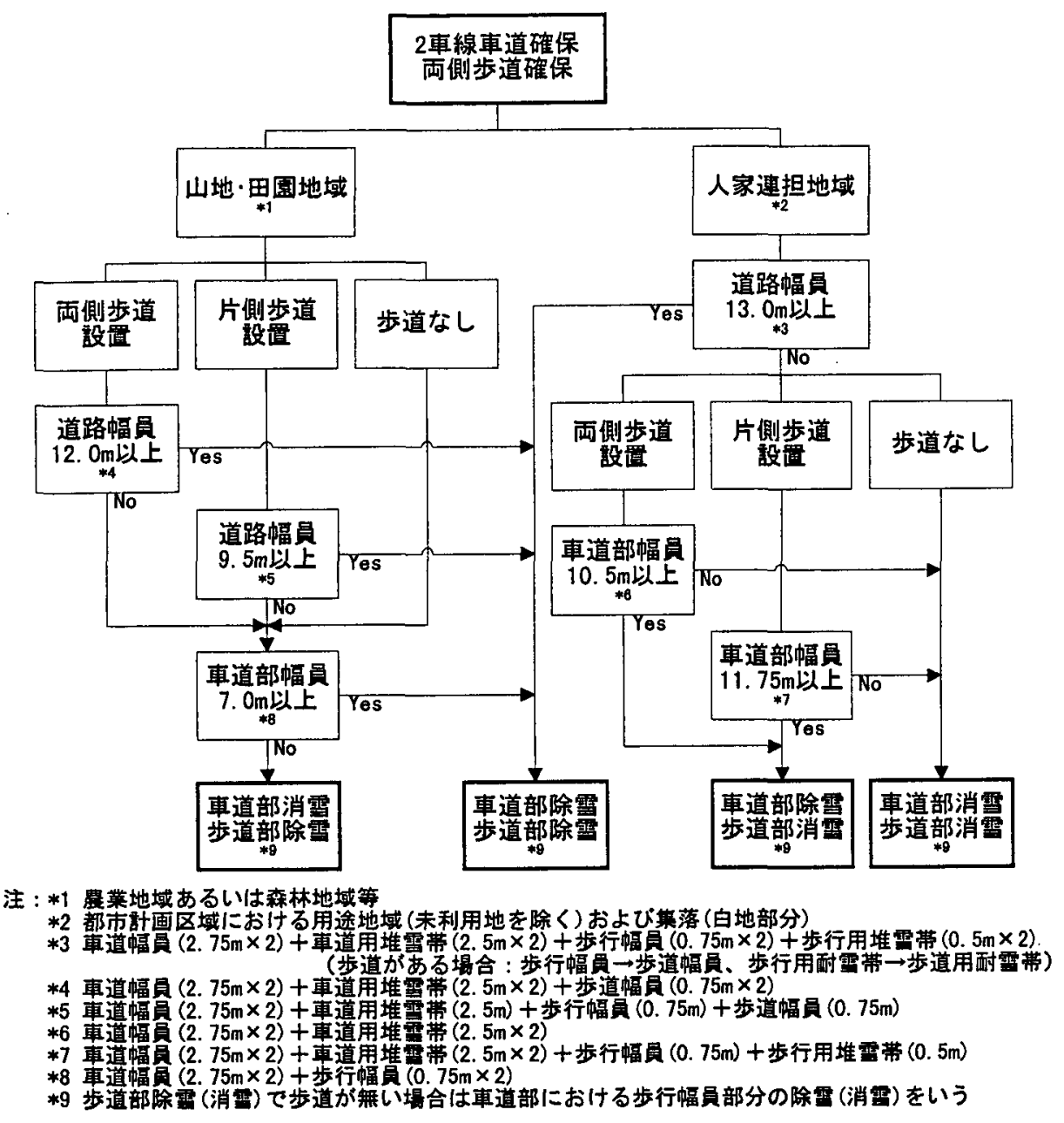

図-3 除雪・消雪道路の選定手順（2 車線車道確保, 両側歩道確保の場合）

は図ー1に示したように幾通りものケースが考えら れるが,ここでは参考までに 2 車線車道確保，雨側 歩道確保の場合についての選定手順を図一 3 に示す。 この手順を適応した結果, 車道部と歩道部 (歩行部) のそれぞれについて，除雪か消雪かを決定できる。 実際には，消雪に選定された道路については，地下 水, 敷設・維持のための費用, 技術的問題などの諸 条件を考慮し，その道路に最む適した消雪方法（例 えば，散水消雪，無散水消雪，排雪など）を決定す る必要があろう。

以上の手順を経て, 最終的に除雪道路の断面構成 が決定できる。ここでは, 車道部 2 車線確保が必要 なケースについてその横断面構成を図ー4に示す。
3. 鯖江市を対象としたケーススタディ

ここでは，福井県鲭江市を対象としたケーススタ ディを行うことで, 除雪・消雪道路の選定手順の実 務への適用性をみる。

\section{1 対象地域の概要}

除雪・消雪道路の選定手順の考え方を適用するに あたり，まず，地域特性を十分把握しておくことが 重要である。

鯖汇市は福井県額北地方のほぼ中央，福井平野の 南に位置している。その東西約 $18.6 \mathrm{~km}$ ，南北約 8.6 $\mathrm{km}$ にわたる市域の多くが平地であるが，東部および 南西の一部が山地となっている(図－5参照)。そ の平地に形成される市の中心市街地である鯖江地区 


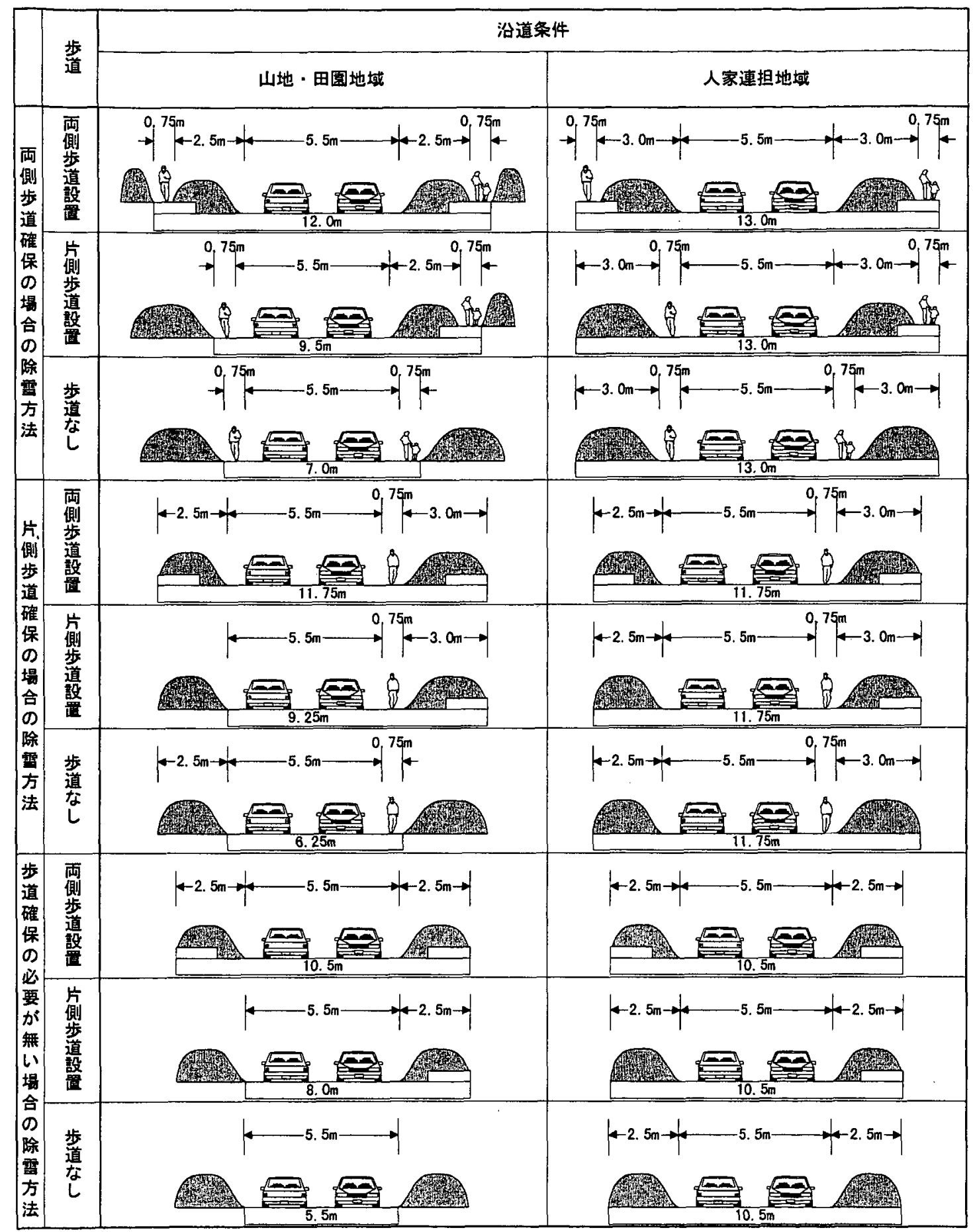

図ー4 浻道条件・歩道状況別にみた除雪方法（2 車線確保の場合） 


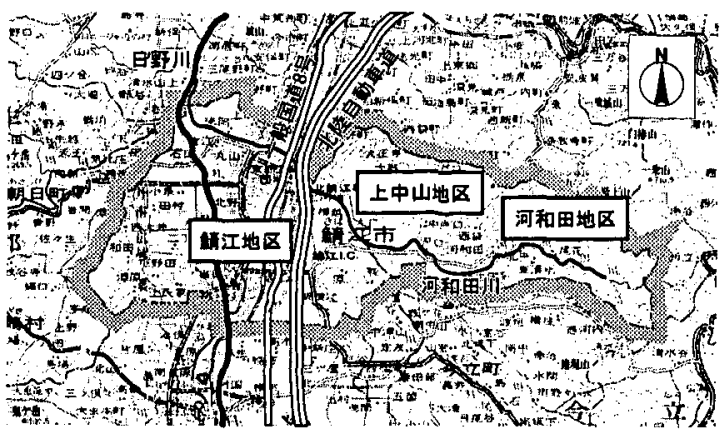

図一 5 鯖江市

から東に向かって山地に属する河和田地区へと至る。 主要な幹線道路としては国道 8 号, 北陸自動車道が 南北を縦断している。主な河川としては，日野川が 鲭江地区西部南北に䋛貫している他，河和田川か 河和田地区を上流として市の東西を横断し，市北部 で日野川と合流している。

鲭江地区，河和田地区，その中間に位置する上中 山地区の 3 地区ごとの降積雪状況を表一 3 に示す。 これをみると，上中山・河和田地区における積雪が 鲭江地区のそれを大きく上回る結果になっているこ とがわかる。なおこの地域において，本研究で設定 した最大積雪深 $80 \mathrm{~cm}$ を超える確率は，30年に 7 回程 度である。

次に，現在実施されている対策を表一 4 に，道路 交通における雪害対策上の課題を表ー5にそれぞれ 整理する。

このように，除雪は市内のほぼ全域で行われては いるものの, 消雪装置の設置は主要幹線が対象となっ ている。一方，対象地区においても消雪装置のため の水資源問題が存在しており，住民から消雪装置を 要求されている道路すへてて設置することは困難で ある。以上より，本対象地区では除雪・消雪道路の 選定が必要とされている。

\section{2 選定手順の適用}

ここでは，消雪装置が設置されていない道路を対 象に，選定手順を適用する。

まず，対象道路を主要交差点によりリンクに分割 する。除雪・消雪道路の選定手順を適用するにあた り，その前提条件となる街路機能，沿道状沉などに ついてまとめた道路カルテを表一 6 に示す。
表一 3 各地区の降䅣雪状況

\begin{tabular}{|c|c|c|c|c|}
\hline & & $\begin{array}{c}\text { 鱎江 } \\
\text { (鯖江) }\end{array}$ & $\begin{array}{c}\text { 上中山 } \\
\text { (上戸ノロ }\end{array}$ & $\begin{array}{l}\text { 河和田 } \\
\text { (上河内) }\end{array}$ \\
\hline \multirow{2}{*}{$\begin{array}{r}\text { 降積雪日数 } \\
\text { (日) }\end{array}$} & 平均 & 22.9 & O 31.5 & 27.4 \\
\hline & 最大 & 55.0 & O $\quad 66.0$ & 58.0 \\
\hline \multirow[t]{2}{*}{ 降雪累計 } & 平均 & 185.7 & O 284.1 & 275.6 \\
\hline & 最大 & 501.0 & 787.0 & O 901.0 \\
\hline 最大日 & 平均 & 23.4 & $\begin{array}{ll}33.4 \\
\end{array}$ & 33.2 \\
\hline 降雪量 & 最大 & 53.0 & 82.0 & $\bigcirc \quad 92.0$ \\
\hline 最深 & 平均 & 47.0 & 72.9 & 086.3 \\
\hline 積雪量 & 最大 & 175.0 & 223.0 & ○ 348.0 \\
\hline
\end{tabular}

O: 3 地区のうちで最大值

表一 4 現在実施されている対策

\begin{tabular}{|c|c|}
\hline 除雪 & 市内道路の約 8 割が除雪対象 \\
\hline 消雪 & $\begin{array}{l}\text { 市街地・家屋連担地区を中心として主要幹線、坂 } \\
\text { 路、橋梁部等に設㯰 }\end{array}$ \\
\hline 流雪鋴 & 横越地区、河和田地区に整備 \\
\hline 排雪 & $\begin{array}{l}\text { 栍雪がおおむ执 } 1 \mathrm{~m} \text { を超える場合に } 14 \text { 個所ある } \\
\text { 雪捨て場に運搬車により排雪 }\end{array}$ \\
\hline
\end{tabular}

\section{表一 5 雪害対策上の課題}

\begin{tabular}{|c|c|}
\hline 除雪 & $\begin{array}{l}\text { 防災扰点へのアクセス道路の確保 } \\
\text { 細街路の除雪 } \\
\text { 步行空間の確保 }\end{array}$ \\
\hline 消雪 & 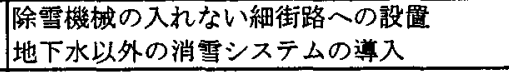 \\
\hline 排雪 & 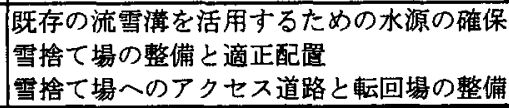 \\
\hline
\end{tabular}

この表より，まず自動車交通・歩行者交通の重要 度ランクを決定する。自動車交通の場合のランク分 類の結果を図一 6 に示す。なお，図中のランクは該 当する最上位のランクで示している。

次に除雪・消雪道路の選定を行う。まず，各道路 の自動車交通, 歩行者交通それぞれの重要度ランク と車線数や街路機能から, 確保の必要な道路断面が 設定される。その結果加ら，各道路断面ことに作成 された除雪・消雪道路の選定手順（図一-3）を用い ることにより，各道路の除雪・消雪方法が選定でき る。その結果を図ー7に示す。最後に，図ー 4 に示 した除雪方法が, 除雪道路の各リンクごとに決定で きる。 
表一 6 道路カルテ

\begin{tabular}{|c|c|c|c|c|c|c|c|c|c|c|c|c|c|c|c|c|c|c|c|c|c|c|c|}
\hline 区 & 道 & 路 & 延 & 沿 & 耳 & E & 道 & & 道 & & & 自 & 動 & 車 & 交 & & & & 行: & 者交 & & 碓 & 磳 \\
\hline 間 & 路 & & & 道 & 車 & $\begin{array}{l}\text { 道 } \\
\text { g }\end{array}$ & 車 & $\begin{array}{l}\text { 右 } \\
\text { 歩 }\end{array}$ & $\begin{array}{l}\text { 左 } \\
\text { 步 }\end{array}$ & $\begin{array}{l}\text { 重 } \\
\text { 要 } \\
\text { 度 }\end{array}$ & & ン & & & & ラン & " III & ラン & & ラン & & 保 & 保 \\
\hline 番 & 理 & 䠞 & & 状 & 線 & & & $\begin{array}{l}\text { 道 } \\
\text { 幅 }\end{array}$ & $\begin{array}{l}\text { 道 } \\
\text { 幅 }\end{array}$ & 機 & 教 & 協 & $\begin{array}{l}\text { 生 } \\
\text { 活 } \\
\text { 重趿 }\end{array}$ & 通 & \begin{tabular}{l|} 
公 \\
共 \\
交
\end{tabular} & & $\mid \begin{array}{l}+ \text { 公 } \\
1 \\
\text { 匕 }\end{array}$ & & 製 & $\begin{array}{l}\text { 栵商 } \\
\text { 行 } \\
\text { 者店 }\end{array}$ & 通 & & బే \\
\hline 号 & 者 & 名 & $\begin{array}{c}\text { 展 } \\
\text { [m] }\end{array}$ & 㫛 & 数 & $\begin{array}{l}\text { 員 } \\
\text { mI }\end{array}$ & $\begin{array}{c}\text { 貣 } \\
\text { [m] }\end{array}$ & $\begin{array}{c}\text { 員 } \\
{[\mathrm{m}]}\end{array}$ & $\begin{array}{c}\text { 員 } \\
\text { [m] }\end{array}$ & 能 & 急 & 急 & 脈 & 学 & 通 & 益 & 不共 & 急 & 急 & 僴街 & 学 & 数き & 道き \\
\hline$\frac{106}{107}$ & $\frac{\text { 県 }}{10}$ &  & 400 & & 2 & $\frac{12,0}{70}$ & 7.0 & 2.5 & 2.5 & & & 8 & 0 & & & 0 & 0 & & & & &  & \\
\hline 108 & 基 & 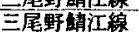 & $\frac{1900}{330}$ & 山地 & $\frac{4}{2}$ & $\frac{.0}{9.5}$ & $\frac{.0}{9.5}$ & - & - & & 0 & 0 & 0 & &  & 0 & 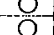 & &  & & & 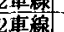 & \\
\hline 109 & 蒖 & 型笔野 & 770 & 人異 & 2 & 12.0 & 7.0 & 2.5 & 2.5 & & 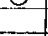 & 0 & 0 & & & 0 & 0 & & - & & & 2 車線 & \\
\hline$\frac{110}{200}$ & 舆 & 三尾野䑤汀線 & 200 & 人家 & 2 & 5.9 & 5.9 & & - & & . & 0 & 0 & & & 0 & 0 & & 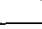 & & & 2車線 & \\
\hline$\frac{200}{201}$ & 䨛 & 上河内湮相 & & 人家 & -1 & $\frac{4.5}{50}$ & $\frac{4.5}{50}$ & & $\ldots$ & & - &  & 0 & 0 & 0 & 잉 & 응 & & & & 잉 & 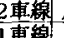 & 牊側 \\
\hline 202 & 萱 & 扎中㳊柏 & & 山地 & $\frac{1}{2}$ & 然.0 & 6.0 & & - & & - & & & 0 & & & 0 & & & & 0 & 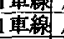 & 年側 \\
\hline 203 & 市 & 北中沢線 & 1580 & 山地 & 2 & 6.0 & 6.0 & & - & & & & & & & & 응 & & & & & 1 重線 & \\
\hline$\frac{204}{205}$ & 罭 & 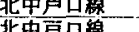 & 480 & 소울 & $-\frac{1}{2}$ & 5.0 & 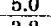 & & 19 & & & & 0 & $\mathrm{O}$ & O & 응. & 0 & & 응 & & 음 & 重線 & 雨俔 \\
\hline 206 & 市 & 北中可口裸 & $\frac{400}{2200}$ & 人傢 & $\frac{2}{2}$ & $\frac{3.0}{5.8}$ & 5.8 & & 1.2 & & & 0 & 0 & 0 & $\frac{U}{0}$ & 0 & 0 & & 0 & 0 & 0 & 里梗線 & 奥商倒 \\
\hline 207 & 市 & & 720 & 人家 & 2 & 6.5 & 6.5 & & & & & \% & 7 & & & & & & & & & &  \\
\hline
\end{tabular}

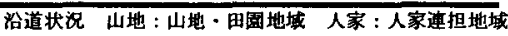



図-6 道路の重要度ランク

\section{4.まとめ}

本研究では, 積雪時における都市内道路の交通確 保に必要とされる除雪・消雪道路の選定をより合理 的に実施する手法を示した。得られた成果は以下の とおりである。
- 自動車交通・歩行者交通の重要度ランク・車線数 等から確保すべき車線数と歩道を設定する方法を 示した。

- 各道路の沿道条件・道路幅員等から, 必要とされ る道路断面を確保するために，車道および歩道の 




\section{図一 7 除雪・消雪道路の選定結果}

それぞれについて，除雪か消雪かを選定する手順 を作成した。

・福井県鯖江市の道路に対して, 道路カルテを作成 し選定手順の適用を行った。この結果は，鯖江市 の除雪・消雪対策に適用されている。

最後に，本論文で提示した選定法の将来性につい て述べる。ここで示される方法は，沿道条件を考慮 した除雪・消雪道路の選定を行うものであり，この 手法を実務において適応するためには，地下水，費 用，技術的問題などの諸条件を考虑したより詳細な 雪害対策の選定手順が必要である。このようなこと から，沿道状況などのさまざまな環境条件を入力し た GIS と組み合わせることにより，各道路に対す る除雪・消雪の選定作業をより合理化できる。また， その結果として，雪害対策にかかる総コストの算出 による費用便益分析といった応用も考えられるだろ う。

謝辞 : 本論文の執筆にあたり，鯖汇市建設部土木課 より資料等の支援をうけた。ここに記して感謝の意 を表する。

\section{参考文献}

1）佐藤英則, 加藤勝彦, 渡邊 亮 : 六日町道路消 雪パイプ集中管理システム導入について，土木 計画学研究・講演集, 20-1, pp.31-34, 1997.

2）大熊 孝, 米内弘明, 小野田勲, 小林雄二 : 消 融雪溝の雪処理能力とその標準的設計法，土木 学会論文集, 371/IV-5, pp107-114, 1986.

3）金子浩明，本多義明，川上洋司：排雪需要を考 慮した雪捨て場配置計画，都市計画論文集，25， pp.721-726, 1990.

4) 木俣 昇 : 除雪路の順位決定のための参加型シ ステムに関する基礎的研究，土木計画学研究・ 論文集，3，pp.57-64，1986.

5 ) 宮腰和弘, 松本昌二, 市街地除排雪に対する住 民の意識構造とその定量化，日本都市計画学会 学術研究論文集, 27, pp.577-582, 1992.

6 ）社団法人日本道路協会, スノートピア策定の手 引き(案), p.35, 1985. 